\title{
Forensic Accounting and the Combating of Economic and Financial Crimes in Ghana
}

\author{
Evans O. N. D. Ocansey, (Lecturer, PhD in Progress, M. Sc.) \\ Valley View University, School of Business, Accra, Ghana
}

Doi: 10.19044/esj.2017.v13n31p379 URL:http://dx.doi.org/10.19044/esj.2017.v13n31p379

\begin{abstract}
Economic and financial crimes have plagued every corner of the economies of the world. These crimes affect all firms and the economies of nations (developed, developing and under-developed). Continuous research confirmed a strong demand for the need of the prevention and detection of these crimes by institutions and nations. However, economic and financial crimes are difficult to detect and most of those detected are not reported for the fear of bad publicity and loss of investor confidence. Forensic accountants are perceived to have the training and skills needed to combat economic and financial crimes. Therefore, the research examined the relevance of forensic accounting technique application in the combating of these crimes in Ghana. The research employed survey research design by sampling all the technical officers (66) of Economic and Organized Crime Office of Ghana and data was analyzed through a regression model. It was found that, the application of forensic accounting technique has significant impact on the combating of economic and financial crimes in Ghana. Therefore, all institutions (anti-corruption agencies and companies) should establish forensic accounting unit to help strengthen internal controls and ensure thorough investigation in order to prevent, deter and detect financial and economic crimes. Moreover, Institute of Chartered Accountants-Ghana and National Accreditation Board of Ghana should ensure that forensic accounting courses are included in the academic and professional curricula of Ghana Universities and professional institutions to ensure the training and increase the awareness of forensic accounting in Ghana.
\end{abstract}

Keywords: Economic and financial crimes, Forensic Accounting, Fraud, Corruption

\section{Introduction}

Economic and financial crimes (EFCs) have plagued every corner of the world's economies of which Ghana is no exception. These crimes affect 
all firms and economies of nations (developed, developing and underdeveloped) (Ocansey, Adegbie \& Dada, 2015; Association of Certified Fraud Examiners, 2012). Therefore several research works on the cost of these crimes were done. Kahan (2006) explained that continuous research confirmed a high demand of the prevention and uncovering of these economic and financial crimes by institutions and nations as a response to closer scrutiny of the economic and financial activities of shareholders and government agencies. However, economic and financial crimes are difficult to detect, and most of those detected are not reported for fear of bad publicity and loss of investor confidence.

Even though the origin of Forensic Accounting could be traced to 1817 (Crumbley, 2001) and was coined in 1946 by Peloubet (Joshi, 2003), it is gaining dominance in fighting against economic and financial crimes. Forensic Accounting emerged in response to the high incidence of frauds (Modudgu \& Anyaduba, 2013; Ozkul \& Pamukcul, 2012). Forensic Accountants are perceived to have the training and skills needed to fight these economic and financial cankers. Therefore, the need to examine the application of forensic accounting and the combating of EFCs is very imperative. With this, the American Institute of Certified Public Accountants (AICPA) indicated that fraud accounting professionals would be in high demand in few years to come and developed Certified Financial Forensics (CFF) to increase the expertise of Certified Public Accountants (American Institute of Certified Public Accountants, 2008).

The Institute of Chartered Accountants, Ghana identified the need to work on the skills of auditors with the intention to offer diploma in Forensic Audit programs (Mr. Addo-Technical Director, personal communication, January 12, 2014). Though auditing may uncover some economic and financial crimes, detailed disclosure of these crimes and their prosecution demand special techniques and forensic accounting is perceived to provide these techniques. Also, forensic accounting has the role of bridging audit expectation gap relating to fraud prevention, detection, and prosecution of economic and financial crime.

Forensic accounting comprises investigation, litigation support and dispute resolution (Dada, Enyi \& Owolabi, 2013) and the upsurge in economic and financial crimes in countries and the world as a whole accentuated the need for the application of its techniques (Modugu \& Anyaduba, 2013). Consequently, forensic accounting is perceived as a tool for combating economic and financial crimes. Thus, the effective application of forensic accounting technique can investigate and detect economic and financial crime cases. Owolabi, Dada, and Olaoye (2013) added that forensic accountant might implement similar financial audit techniques, nonetheless with different objective and procedures; and may 
validate calculations needed by scrutinizing a trail of paperwork to achieve a specific goal of the engagement. Hence, the use of forensic accounting techniques could enhance the prosecution of economic and financial crime cases. It is therefore imperative to carry a research on economic and financial crimes and the relevance of forensic accounting techniques in combating these crimes in Ghana. Consequently, this research seeks to determine the relevance of forensic accounting technique in combating economic and financial crimes in Ghana.

\section{Literature Review}

\section{Forensic Accounting (FA) Overview}

Many people are unfamiliar with forensic accounting even though it is dated back to the early part of the 1800s. Mitrić, Stanković, and Lakićević (2012) indicated that forensic accounting practice could be dated back to 1817, where a decision of a court on bankruptcy was based on the testimony of an accountant. They further indicated that a Scottish accountant used his knowledge and expertise through opinion to support arbitration proceedings in the 1820s. Several articles examined revealed expert testimonies and evidence on arbitration in the late 1800s and the early 1900s. However, "forensic accounting" was used by Kautilya who stated several means of embezzlement, but the term was coined in 1946 by Peloubet (Joshi, 2003; Crumbley, 2001). That is, forensic accounting is not new in the world; nonetheless, many countries are yet to grow this profession even though they need it badly.

Though forensic accounting is dated back to the 1800 s, it was noted from the review that there is no single definition for it. It is also known as investigative or fraud audit or even judicial accounting and is the unification of accounting, auditing, investigation, and law. Crumbley (2003) explained forensic accounting as the examination and interpretation of legal facts and evidence, and expert witnessing in the court of law.

Apostolou, Hassell, and Webber cited in Modugu and Anyaduba (2013), also indicated that forensic accounting is a specialized accounting field which makes use of auditing and with investigative skills to assist in legal matters that arises from activities of current and potential disputes or litigation. Therefore it is an aspect of accounting that is suitable for a higher level of assurance for law courts. In other words, it is the combination of accounting, auditing and investigation skills to uncover the truth. It uses generally accepted accounting, auditing principles, and accounting expertise to establish losses or gains, property, damages, the effectiveness of internal controls and frauds for the legal system usage regarding criminal and civil disputes (potential or actual) (Zysman, 2001). Thus, it is accounting suitable for legal proceedings; hence, it gives the highest level of assurance through 
the use of scientific approaches to arrive at generally accepted connotation (Akintoye, 2008; Crumbley, 2006) and providing the needed findings in settling disputes. In summary, it is a specialized area of accounting that employs accounting, auditing, investigative and legal skills and knowledge to provide evidence of information suitable or relevant to legal issues. Simply put, it is accounting spoken in the language of the law.

\section{Forensic Accounting Skills and Techniques}

Based on the characteristics of fraudsters, forensic accountants need special skills. Recently, the Federal Bureau of Investigation of United States of America estimated that more than three hundred billion dollars (\$300) is loss annually to fraud (Federal Bereau of Investigation, 2006) and many of these crimes are difficult to identify due to the concealment of the perpetrators' activities. Consequently, American Institute of Certified Public Accountants (AICPA) suggested that more forensic accounting techniques and procedures should be incorporated in the detection of financial reporting since auditors and forensic accountants have different training, skills and mindsets (American Institue Certified Public Accountants, 2004; International Option Market Association, 2004). Therefore, to handle the issue of economic and financial crimes (EFCs), forensic accountants must possess unique skills. From these explanations of forensic accounting techniques and skills, it logically follows that; forensic accountants possess special and specific skills.

Further, Ramaswamy (2005) posits that forensic accountants have distinct and positioned themselves and can uncover financial deceptions. That is, they possess the prominent skills and competencies which can aid the uncovering of deceit. In that, knowledge of psychology and law, creative thinking, and strong communication skills can be of great help to forensic accounts. These skills will help them in understanding the reasons behind the behaviors of perpetrators, the legal and ethical issues, and communicate facts and evidence to people who have less or no knowledge of accounting. Analytical and good writing skills are also very critical in discovering concealed information (Crumbley, Heitger \& Smith, 2009; Messmer, 2004). McMullen and Sanchez (n. d.) investigated the skills or traits and the rationale behind the skills of forensic accountants. They indicated that, since accounting is considered as the "language of business," fundamental accounting skills cannot be omitted. They further indicated that the level of education does have a major role in equipping forensic accountants for their job.

Crumbley, Smith, and Apostolou (2007) added that forensic accountants need to document their work hence need writing communication skills to enable them to give a well-written report to help impress the jury in 
litigation. Sanchez and Trewin (2004) added that forensic accountants might serve as expert witnesses in giving testimonies for litigation support by communicating complicated facts and evidence for judges to comprehend. Hence verbal communication skills are crucial to the success of forensic accountants. Prior auditing experience with law enforcing institution and personal skills are added advantage or needed skills (Wells, 2003).

In this technological world, computer forensic and data mining knowledge are also vital to uncovering technological frauds. The work of forensic accountant goes beyond uncovering of the truth. It also helps in the prosecution of perpetrators, knowledge of criminal justice or law enforcement is very vital. All these discussions affirmed Kahan (2006) who indicated that there are continuous validations that the prevention of fraud and uncovering of deceptive accounting practices are in demand. Hence, there is increasing demand for forensic accountants.

\section{Combating of Economic and Financial Crimes}

A review of the literature on fraud disclosed that economic and financial crimes (EFCs) are growing problems in the world (Adams, Cambell, Cambell \& Rose, 2006; Hochberg, 2006; Peterson \& Zikmund, 2004; Wells, 2007). A further review of the literature on EFCs revealed that they have an impact on the world's economies (Association of Certified Fraud Examiners, 2006; Ernst \& Young, 2000; Peterson \& Zikmund, 2004). In response to these EFCs, many governments have championed the fight against EFCs in the history of Ghana. Currently, the Government of Ghana seeks to ensure assets declaration of all government officials, strengthen the mandate of the auditor-general and use of technology (paperless systems) to reduce EFCs.

Also, the Ghana Shared Growth and Development Agenda identified and documented capacity, collaboration and coordination as very pertinent to the effective and efficient smooth working of anticorruption institutions. Therefore, the medium-term economic framework adapted the following strategies to fight against EFCs. The implementation of the right to information bill, Public Procurement Act 2003, 663; Internal Audit Agency Act 2003, 658; the Whistleblower's Act and other Public Financial Management Laws are all in response to the combating of EFCs.

\section{Forensic Accounting Techniques and Combating of EFCs}

The outgrowth of the increased in EFCs birthed forensic accounting and made it an embryonic topic of importance for academic and industrial research. The studies of Okunbor and Obaretin [38], Okoye and Gbegi [39], Modugu and Anyaduba (2013), Kasum (2009) and Nunn, McGuire, Whitcomb and Jost (2006) on the effectiveness of forensic 
accounting in fraud control produced different results. These research works did not consider whether the use of forensic accounting techniques can help fight EFCs.

Alabdullah, Alfadhl, Yahya, and Rabi (2014) intimated that scholars saw the rise of forensic accounting as very essential thing. They added that corruption requires sophisticated ways to understand modern methods. The study of Boateng, Longe, Mbarika, Avevor, and Isabalija (2010) was concerned with cybercrimes. Their findings indicated that the Ghana Police Service lacks the technical skills and training required to combat EFCs but they did not consider the technical skills and training that are needed. Also, it did not consider an alternative technique that can be used to combat EFCs in Ghana. The emergence of Information and Communications Technology and the fast development of the financial sector, financial institutions saw the need to combat EFCs. OforiDwumfuo and Gyimah (2013) noticed that the prospect of using business intelligence to detect financial crimes, but they also did not consider those who make use of business intelligence and training needed to combat EFCs.

Adegbie and Fakile (2012) indicated that corruption and other financial and economic crimes are the bane of Nigerian development efforts and harm the economy. They perceived lack of the appropriate litigation support services in the court is a principal cause of misjudgment. Dada, Enyi, and Owolabi (2013) saw corruption as a prevalent topic of debate in both Nigeria and other parts of the world, and several cases of bribery. Anomah, Ayeboafo, and Agyabeng (2014) opined that many third world countries are encumbered with high corruption and poor ranking of corruption perception index as a result of weak regulatory environments. They added that flaccid attitude of statutory audit toward fighting EFCs failed to provide the needed assurance enshrine in audit requirements.

\section{A Conceptual Model for Combating EFCs}

The conceptual model below indicates the relationship among Combating of Economic Financial Crimes (CEFC), Audit Expectation Gap (AEG), Forensic Accounting Techniques (FAT), Academic and Professional Curricula (APC) and Cost of Economic and Financial Crimes (CoEFC). CoEFC comprises financial fraud $\left(\mathrm{EFC}_{\mathrm{F}}\right.$ and corruption $\left(\mathrm{EFC}_{\mathrm{C}}\right)$. GDP is used as a surrogate of the economy of Ghana. That is, for a country to successfully combat economic and financial crimes, anti-corruption agencies should consider AEG (relating to standards, performance, liability, and fraud detection and prosecution), assessed the use of FAT in combating EFCs, analyze the CoEFC and explore the need of forensic accounting in the APC 
of Ghana. Thus, the model gives the snapshot of factors that should be considered in the combating of EFCs.

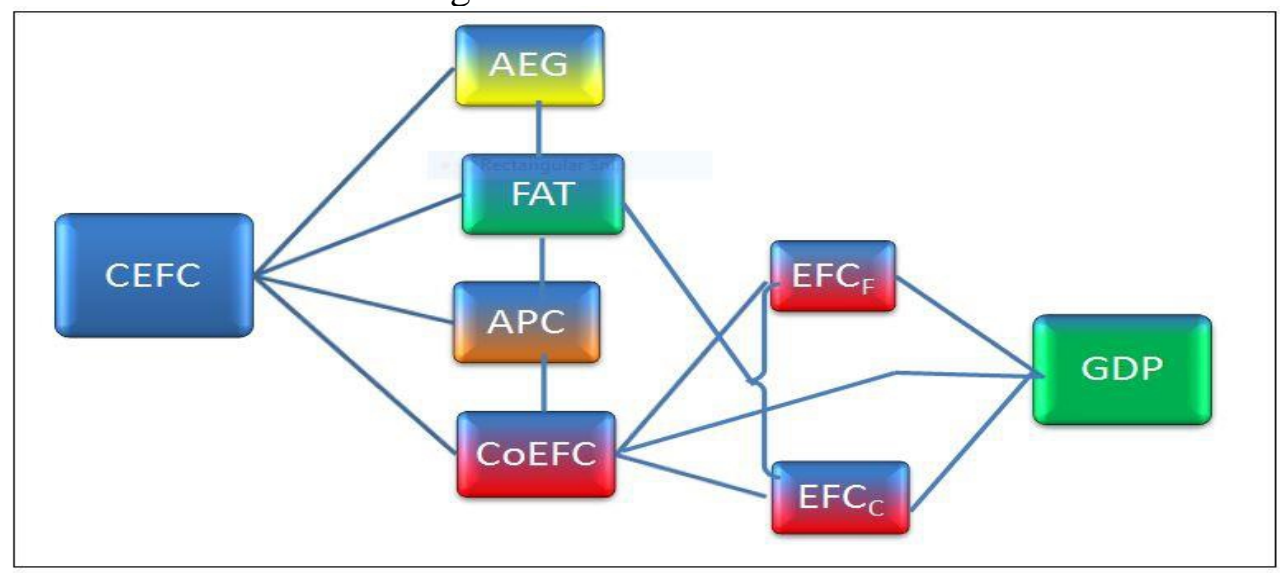

Figure 1. A Conceptual Model for Combating EFCs in Ghana

Source: Ocansey (2015)

This research did not cover all the variables of in the model for combating EFCs but a portion. In other words, this research is one of the series of articles being published from dissertation of the researcher. Therefore other articles will cater for the portions of this model that are not covered.

\section{Theories of Economic and Financial Crimes (EFCs)}

There are several theories that explain why people perpetrate EFCs. The review of previous research works revealed that agency theory was linked with corporate governance (Caldwell \& Karri, 2005; Corley, 2005; Roberts, McNutty \& Stiles, 2005), or stakeholder theory linked with ethical business theory (Rodin, 2005) and agency theory with differential theory (Bejarano, 2008). Thus, studies usually combined two theories to explain the behavior of fraudster. However, this research adapted a different approach to exploring why people commit EFCs and how to combat them by combining the theories of fraud triangle, fraud diamond, and fraud management. This approach may supplement and complement previous research in the field of EFCs and also explain the expected criminal behavior of EFCs perpetrators and how to eradicate or minimize their execution.

The fraud triangle theory is most often used to examine the perpetration of EFCs (Peterson \& Zikmund, 2004; Wells, 2007). Albrecht, Turnbull, Zhang, and Skousen (2010) explained this theory by emphasizing that, fraud is usually perpetrated when there is pressure from many situations, a high opportunity is perceived, and there is low integrity. Thus, these cardinal three conditions were widely considered to be the bedrock of the perpetration of EFCs. 
However, in recent literature, the three triangle theory was criticized. Wolfe and Hermanson (2004) and Carcillo and Hermanson (2008) indicated that one may have the incentive or pressure, opportunity and can rationalize but may not have the ability or capability to perpetrate EFC. Therefore, they expanded the fraud triangle by adding another part making a fraud diamond. In other words, the fraud diamond theory posits that the capability and personality traits can encourage or discourage the commitment of fraud. That is, opportunities can be available for a person, motivation can be high, good rationalization due to poor integrity may be available, but if the person does not possess a special skill or capability to capitalize on the loophole seen, the fraud cannot be committed.

Wilhelm (2004) developed the Fraud Management Lifecycle. It has eight stages with interrelated activities geared toward managing fraud. These eight stages are prevention, deterrence, detection, mitigation, analysis, policy making, investigation, and prosecution. These stages are independent actions but can be performed simultaneously. It is a representation of non-linear activity.

\section{Research Methodology}

This study used survey research design to examine the relevance of forensic accounting techniques in the combating of economic and financial crimes in Ghana. This research collected primary data with the help of research questionnaire from the all technical officers (66) of the Economic and Organized Crime Office of Ghana, the anti-corruption body mandated to combat economic and financial crimes. That is, a purposive sampling technique was employed for this research.

Questionnaire items were designed based on the research objective. Consequently, a 5-point Likert scale consisting of strongly agreed (SA) agreed (A), undecided (UD), disagreed (D) and strongly disagreed (SD) were used to solicit the opinion of respondents. This choice has been informed by previous research works (Bhasin; 2007; Adegbie, 2012). To ensured that the research instrument assessed all its construct of interest, measured the characteristics of research variables and measured what it was intended to measure, questionnaire items were thoughtfully selected from previous studies which tested and measured similar research objective and were designed based on research objectives. Also, people who are well-informed and experts in the area of this study checked and approved instrument items and their ability in meeting objectives. Besides, the research constructed closed-ended questionnaire items, used simple words to enhance understandability and easy answering and tabulated to ease fatigue of respondents. The researcher personally went to the sampled institution premises to administer copies of the questionnaire. The copies of the 
questionnaire were collected personally after their completion. Data collected (primary) were analyzed using simple linear regression model.

\section{Data Analysis and Interpretation of Findings}

Table 2. Results.

\begin{tabular}{llllllll}
\hline & $\mathrm{R}$ & R Square & Std. Error & B & F & t & Sig. \\
\hline CEFC & .767 & .589 & .23548 & .589 & 27.655 & 6.540 & .000
\end{tabular}

As shown in Table 2, the t-test result for the regression coefficient for the independent variable (FAT) was 6.540 with a significance of .000 . These meant that the probability of this result occurring by chance was less than 0.005 . Hence, the coefficient of FAT was statistically significant at the $\mathrm{p}<$ 0.05 level. That is, statistically, FAT is very significant in influencing the combating of economic and financial crimes. Therefore, we reject the null hypothesis (Forensic accounting technique application has no significant relevance to combating economic and financial crimes in Ghana). This implies that the use of FATs can facilitate the combating of EFCs in Ghana. Consequently, if anti-corruption agencies and other institutions apply FATs in the combating of EFCs, they will reduce.

The study again brought to bear that, statistically the application of forensic accounting technique has a significant impact on the combating of economic and financial crimes in Ghana; because the t value of FAT was less than 0.005 (.000). Thus, the problem of economic and financial crimes could be minimized by the application of forensic accounting techniques. This result is in contrast to the research results of Okunbor and Obaretin [38] which found that the application of forensic services is not effective in deterring fraudulent activities.

However, the result is consistent with the research results of Modugu and Anyaduba (2013) which indicated that the use of FATS could control financial fraud, financial reporting, and internal control quality. This result was also affirmed by Okoye \& Gbegi (2013) that the application of FATs will significantly reduce the occurrence of fraud cases in the public sector. Several other research works confirmed that FATs play a significant role in curbing economic and financial crimes. Adegbie and Fakile (2012) also found that forensic accounting can be used as a financial and strategic tool to curb and resolve economic and financial crimes. Owolabi, Dada, and Olaoye (2013), and Dada, Enyi, and Owolabi (2013) all agreed that the application of FATs could aid in the detection and investigation of bribery cases. Moreover, Anomah, Ayeboafo, and Agyabeng (2014) discovered that FATS have positive potential in tackling economic and financial crimes. Again, Nunn, McGuire, Whitcomb, and Jost (2006) revealed that there is high demand for forensic accountants due to the crucial their role in investigating 
financial scandals and asset misappropriation, and they bring independence and credibility to these investigations.

\section{Conclusion and Recommendations:}

Since the research has revealed that, FATs can play a major role in combating EFCs in Ghana, policy makers can rely on this finding and formulate policies relating to the combating of economic and financial crimes. Also, the Chartered Institute of Accountants-Ghana, the regulating body of accounting practitioners can take a clue to ensure that accountants are trained to use these techniques.

More so, institutions can take the findings as a reference point to establish forensic accounting units in their internal audit departments to strengthen their internal controls, and also ensure a thorough investigation of economic and financial crimes. The service of forensic accountants would help prevent, deter and prosecute EFCs in Ghana.

Anti-corruption agencies and law enforcing institutions should train personnel to use forensic accounting techniques to uncover the truth to enable easy prosecution of EFC cases. This will help prevent EFCs cases thrown out of court for lack of sufficient evidence in Ghana. The use of forensic accounting techniques can help provide enough evidence for easy judgment. More so, the services of professional accounting firms which have forensic accountants should be used for the investigation of corruption practice to encourage prosecution.

Many anti-corruption laws have been enacted in Ghana. These laws should be implemented to the core to propel economic growth of Ghana without the attendant effect of EECs.

Further, the government of Ghana should increase the interest in and facilitate the growth of forensic accounting for proper monitory and investigation of alleged corruption cases by giving legal backing to forensic accounting.

Establishing that forensic accounting techniques are relevant to combating of economic and financial crimes in Ghana, forensic accounting courses should be included in the academic and professional curricula of Ghana Universities and professional institutions to train and increase the awareness of forensic accounting in Ghana.

The study's limitation is that it surveyed the employees of Economic and Organized Crime Office of Ghana. To address this limitation, only technical officers of Economic and Organize Crime Office - the body with the legal mandate to combat economic and financial crimes were used. That is only people with expert knowledge were used for the study. Therefore, the findings can still inform the combating of economic and financial crimes in Ghana and beyond. 


\section{References:}

1. Adams, G. W., Campbell, D. R., Campbell, M., \& Rose, M. P. (2006). Fraud Prevention. CPA Journal, 76(1), 56-59.

2. Adegbie, F. F., \& Fakile, A. S. (2012). Economic and Financial Crime in Nigeria: Forensic Accounting as Antidote. British Journal of Arts and Social Sciences, 6(1), 37-50.

3. Akintoye, I. R. (2008). The Basics of Environmental and Forensic Accounting. Akoka-Yaba: Unique Educational Publishers.

4. Alabdullah, T. T. Y., Alfadhl, M. M. A., Yahya, S., \& Rabi, A. M. A. (2014). The Role of Forensic Accounting in Reducing Financial Corruption: A Study in Iraq. International Journal of Business and Management, 9(1), ISSN 1833-3850 E-ISSN 1833-8119.

5. Albrecht, C., Turnbull, C., Zhang, Y., \& Skousen, C. J. (2010). The Relationship between South Korean Chaebols and Fraud. Managerial Auditing Journal, 33(3), 1-25. https://doi.org/10.1108/01409171011030408. Retrieved from http://www.emerald.com

6. American Institute of Certified Public Accountants. (2004). Discussion Memorandum: Forensic Services, Audits, and Corporate Governance: Bridging the Gap. Retrieved from http://www.bvfls.aicpa.org

7. American Institute of Certified Public Accountants (2008). Retrieved from

http://www.fvs.aicpa.org/Memberships/Overview+of+Certified+in+F inancial+Forensics+Credential.htm

8. Anomah, S., Ayeboafo, B., \& Agyabeng, W. (2014). Forensic Accounting - A Multifaceted Standard for Cleaner Stewardship in Weak Regulatory Environments. Research Journal of Finance and Accounting, 5(2). Retrieved from http://www.iiste.org

9. Association of Certified Fraud Examiners (ACFE) (2006). Report to the Nation on Occupational Fraud \& Abuse. Retrieved from http://www.acfe. com/fraud/report.asp

10. Association of Certified Fraud Examiners (ACFE) (2012). Report to the Nations on Occupational Fraud and Abuse. Retrieved from http://www.acfe.com/uploadedFiles/ACFE_Website/

Content/rttn/2012-report-to-nations.pdf

11. Bejarano, J. R. (2008). Mitigating Corporate Financial Fraud: A Qualitative Study (Doctoral thesis). Retrieved from http://www.gradworks.umi.com/3338359.pdf

12. Bhasin, M. L. (2007). Forensic Accounting: A New Paradigm for Niche Consulting. The Chartered Accountant (pp. 1000-1010). New Delhi: the ICAI. 
13. Boateng, R., Longe, O., Mbarika, V., Avevor, I., \& Isabalija, S. R. (2010). Cyber Crime and Criminality in Ghana: Its Forms and Implications. Americas Conference on Information Systems (AMCIS) $2010 \quad$ Proceedings. Retrieved from http://aise1.aisnet.org/amcis 2010/507

14. Caldwell, C., \& Karri, R. (2005). Organizational Government and Ethical Systems: A Covenantal Approach to Building Trust. Journal of Business Ethics, 58(1-3), 249-259. https://doi.org/10.1007/s10551005-1419-2

15. Carcillo, J. V. and D. R. Hermanson (2008). Fraudulent Financial Reporting: How Do We Close the Gap? Retrieved from https://pdfs.semanticscholar. org/f4bf/b3c2730f6cceab7d3d957aed3776da96738f.pdf

16. Corley, K. (2005). Examining the Non-executive Director's Role from a Non-agency Theory Perspective: Implications Arising from the Higgs Report. British Journal of Management Supplement, 1(16), 1-4 https://doi.org/10.1111/j.1467-8551.2005.00443.x

17. Crumbley, D. L. (2001). Forensic Accounting: Older than You Think. Journal of Forensic Accounting, 11(2), 181-202.

18. Crumbley, D. L. (2003). What is Forensic Accounting? Forensic Accounting: Older than You Think. Journal of Forensic Accounting, 11(2), 181-202. Retrieved from http://www.edwardpub.com

19. Crumbley, D. L. (2006). Forensic Accountants Appearing in the Literature. Retrieved from http://www.forensicaccounting.com.

20. Crumbley, D. L., Heitger, L. E., \& Smith, G. S. (2009). Forensic and Investigative Accounting. Chicago: Commerce Clearing House.

21. Crumbley, D. L., Smith, G. S., \& Apostolou, N. G. (2007). A Broad Approach to Forensic Accounting is Needed. The Value Examiner, 13-19.

22. Dada, S. O., Enyi, P. E., \& Owolabi, S. A. (2013). Forensic Accounting: A Relevant Tool for Effective Investigation of Bribery Cases in Nigeria. Unique Journal of Business Management Research, 1(5), 095-099. Retrieved from http://www.uniqueresearchjournals.org/ujbmr/pdf

23. Ernst and Young. (2000). Fraud, the Unmanaged Risk: An International Survey of the Effect of Fraud on Businesses. International Survey Ernst and Young. Retrieved from www.E\&Y.com.

24. Federal Bureau of Investigation. (2006). Financial Crimes Report to the Public: Fiscal Year 2006. Retrieved from http://www.fbi.gov/publications/ fcs 
25. Hochberg, N. A. (2006). When Accounting Practices go under the Microscope. Financial Executive, 22(1), 53-55.

26. International Option Market Association. (2004). Report on Financial Analysis, Planning and Reporting. New York: 4(9), 1-11.

27. Joshi, M. S. (2003). Definition of Forensic Accounting. Retrieved from http://www. forensicaccounting.com

28. Kahan, S. (2006). Sherlock Holmes enters accounting; Dramatic increase in fraud brings more CPA sleuths into the industry. Accounting Today, 20(8), 1.

29. Kasum, A. S. (2009). The Relevance of Forensic Accounting to Financial Crimes in Private and Public Sectors of Third World Economies: A Study from Nigeria. Proceedings of the 1st International Conference on Governance Fraud Ethics and Social Responsibility. https://doi.org/10.2139/ ssrn.1384242. Retrieved from http://ssrn.com/abstract=1384242

30. McMullen, D. A., \& Sanchez, M. H. (n. d.). A Preliminary Investigation of the Necessary Skills, Education Requirements, and Training Requirements for Forensic Accountants. Journal of Forensic \& Investigative Accounting, 2(2), 30-48.

31. Messmer, M. (2004). Exploring Options in Forensic Accounting. National Public Accountant, 19-20.

32. Mitrić, M., Stanković, A. \& Lakićević, M. (2012). Forensic Accounting - the Missing Link in Education and Practice. Management Journal for Theory and Practice Management, 65, 4150. https://doi.org/10.7595/management. fon.2012.0032. Retrieved from http://www.management.fon.rs

33. Modugu, K. P., \& Anyaduba, J. O. (2013). Forensic Accounting and Financial Fraud in Nigeria: An Empirical Approach. International Journal of Business and Social Science 4(7), 281-289.

34. Nunn, L. McGuire, B. L., Whitcomb, C., \& Jost, E. (2006).Forensic Accountants: Financial Investigators. Journal of Business \& Economics Research, 4(2), 1-6.

35. Ocansey, E. O. N. D. (2015). Forensic Accounting and Economic and Financial Crimes in Ghana. Unpublished Master's dissertation, Babcock University, Nigeria.

36. Ocansey, E. O. N. D.; Adegbie, F. F., \& Dada, S. O. (2015). Impact of Economic and Financial Crimes on the Economy of Ghana. VVU Journal of Business Research, 1(1), 106-121.

37. Ofori-Dwumfuo, G. O., \& Gyimah, E. (2013). Business Intelligence as an ICT Tool for Financial Crime Detection in Ghana. Research Journal of Information Technology, 5(3), 62-71 
38. Okunbor, J. A., \& Obaretin, O. (2010). Effectiveness of the Application of Forensic Accounting Services in Nigerian Corporate Organizations. Journal of Management Science, 1(1), 171-184.

39. Okoye, E. I., \& Gbegi, D. O. (2013). Forensic Accounting: A Tool for Fraud Detection and Prevention in the Public Sector. International Journal of Academic Research in Business and Social Sciences, 3(3), 2222-6990

40. Owolabi, S. A., Dada, S. O., \& Olaoye, S. A. (2013). Application of Forensic Accounting Technique in Effective Investigation and Detection of Embezzlement to Combat Corruption in Nigeria. Unique Journal of Business Management Research 1(4), 65-70. Retrieved from http://www. uniqueresearchjournals.org

41. Ozkul, F. U., \& Pamukcul, A. (2012). Fraud Detection and Forensic Accounting. Aliyurt, K. C., \& Idowu, S. O. (eds.), Emerging Fraud. https://doi.org/10.1007/978-3-642-20826-3_2 Springer-Verlag Berlin Heidelberg

42. Peterson, B. K., \& Zikmund, P. E. (2004). 10 Truths You Need to Know about Fraud. Strategic Finance, 85(11), 29-34.

43. Ramaswamy, V. (2005). Corporate Governance and the Forensic Accountant. The CPA Journal, 75(3), 68-70.

44. Roberts, J., McNutty, T., \& Stiles, P. (2005). Beyond Agency Conceptions of the Work of the Non-executive Director: Creating Accountability in the Boardroom. British Journal of Management, Supplement 1(16), 5-26. https://doi.org/10.1111/j.14678551.2005.00444.x

45. Rodin, D. (2005). What's Wrong with Business Ethics? International Social Science Journal, 57(185), 561-571. https://doi.org/10.1111/j.1468-2451.2005.00571.x

46. Sanchez, M. H., \& Trewin, J. (2004). A Forensic Accountant as an Expert Witness in a Criminal Prosecution. Journal of Forensic Accounting, 5(1), 231-235.

47. Wells, J. T. (2003). The Fraud Examiners. Journal of Accountancy, 196(4), 76-80.

48. Wells, J. T. (2007). Corporate Fraud Handbook: Prevention and Detection (2nd ed.). Hoboken, NJ: John Wiley \& Sons.

49. Wilhelm, W. K. (2004). The Fraud Management Lifecycle Theory: A Holistic Approach to Fraud Management. Journal of Economic Crime Management, 2(2), 1-38.

50. Wolfe, D. T., \& Hermanson, D. R. (2004). The Fraud Diamond: Considering the Four Elements of Fraud. CPA Journal, 74(12), 3842. 
51. Zysman, A. (2001). Forensic Accounting Demystified: World Investigators Network Standard Practice for Investigative and Forensic Accounting Engagement. Retrieved from www.forensicaccounting.com 